\title{
Attitudes to systemic risk: the impact of flood risk on the housing market in Dublin
}

\author{
Salem S. Gharbia \\ Department of Civil, Structural and Environmental \\ Engineering, Trinity College Dublin \\ Dublin, Ireland \\ GharbiaS@tcd.ie \\ Owen Naughton \\ Department of Civil Engineering, \\ National University of Ireland Galway \\ Galway, Ireland \\ Vincent Farrelly \\ Office of Public Works, Ireland
}

\author{
Ronan Lyons \\ Department of Economics, \\ Trinity College Dublin \\ Dublin, Ireland \\ ronan.lyons@tcd.ie
}

\author{
Francesco Pilla \\ Department of Civil, Structural and Environmental \\ Engineering, Trinity College Dublin \\ Dublin, Ireland \\ fpilla@tcd.ie
}

\begin{abstract}
The concatenated effects of increased frequency of intense precipitations due to climate change and anthropogenic impacts in the form of construction in floodplains, channel straightening and increased presence of impermeable surfaces are increasing the incidence of floods in urban areas. This paper investigates behavioral responses to a natural hazard (flooding) by examining residential property values. The results of this investigation can be used to develop benefit/cost studies to assess the economic merits of policies that mitigates the risk of floods by using the residential housing market as a proxy for estimating these values since the choice of where to live often includes the choice of hazard level. The methodology described here also provides a mechanism for testing consumer behavior under uncertainty. This study uses a hedonic property price function to estimate the effects of flood hazards on residential property values. The study utilizes data from $\mathbf{1 5 8 , 8 9 0}$ residential home sales in Dublin, Ireland between 2006 and 2015. This area experienced significant flooding in October 2011. GIS is used to spatially characterize the houses included in the analysis by linking them to the following set of parameters included into the baseline regression: house price, house type and size (number of bedrooms and bathrooms), when it was on the market, and its location. Once the baseline regression model is built, then the variables included in it are regressed against the flood-risk. The distance between a set of amenities and the properties is also calculated using GIS. Results show that a house located within a floodplain has a lower market value than an equivalent house located outside the floodplain. Finally, the benefits resulting from the use of GIS-based spatial indicators of properties in hedonic regression models to quantify the
\end{abstract}

accessibility to amenities as network travel distances are also demonstrated.

Keywords - Valuation, Environmental risk, Meta-analysis, GIS Spatial Analysis, Hedonic pricing

\section{INTRODUCTION}

The occurrence and consequences of floods receives increasing media coverage worldwide as a result of a higher incidence of these natural disasters. Sizeable human and material losses are associated with flooding disasters, and this is the reason why this paper focuses on this specific type of natural disaster. Climate change is a result of the concatenated impacts of changing natural circumstances and human behavior, causing increases in the frequency and the magnitude of floods. Indeed, there is an increased chance of intense precipitation and flooding due to "greater water-holding capacity of a warmer atmosphere", and it is expected that "such events will continue to become more frequent" [1]. Anthropogenic impacts on river flooding are clearly visible in changed river management practices. Construction in floodplains [2], channel straightening and increased presence of impermeable surfaces such as transport infrastructure and residential areas are examples of urbanization that increases the risk of river floods in small catchment areas and small river networks [3, 4].

This paper investigates behavioral responses to a natural hazard (flooding) by examining residential property values. This type of research is important for at least two reasons. First, the results of this investigation can be used to develop benefit/cost studies which attempt to assess the economic merits of policies that change the likelihood or magnitude of an event [5]. The residential housing markets may provide an 
avenue for estimating these values since the choice of where to live often includes the choice of hazard level. Research on the role of natural hazards in urban housing markets is important also because the methodology provides a mechanism for testing consumer behavior under uncertainty. This was realized by Brookshire [6], who used house price differentials resulting from earthquake hazard in Los Angeles and San Francisco to test predictions from the expected utility model.

This study uses a hedonic property price function to estimate the effects of flood hazards on residential property values. The study utilizes data from 158,890 residential home sales in Dublin, Ireland between 2006 and 2015. This area experienced significant flooding in October 2011. Results show that a house located within a floodplain has a lower market value than an equivalent house located outside the floodplain. Furthermore, the price discount from locating within a floodplain is significantly larger after a flood event than before. The actual occurrence of a flood event or increased stringency in disclosure rules causes ex-ante prices to differ from ex-post prices, but these effects are small. The marginal willingness to pay for reduced risk exposure has increased over time, and it is slightly lower for areas with a higher per capita income. The analysis presented in this paper shows that obfuscating amenity effects and risk exposure associated with proximity to water causes systematic bias in the implicit price of flood risk, in line with was found also by [7], [4] and [8]. It is reasonable to assume that locational amenities are more important to a person who wants to buy a house as oppose to a person who just wants to rent a house and so this could result in the over valuation of amenities during boom periods. Many people in Ireland during the property boom who were first time buyers were willing to pay a high price for low quality amenities and accept the disamenities that came with a property, so as to just get on the property ladder [9]. Previous studies have evaluated the influence of flood risk in the housing market by comparing prices before and after a flood event. For this study, it's proposed to compare prices before a flood event, immediately after a flood event and for an extended period after a flood event in the aforementioned catchment areas and to control of the effects of amenities and disamenities.

\section{MATERIALS}

\section{A. Catchment Flood Risk Assessment and Management Programme}

The national Catchment Flood Risk Assessment and Management (CFRAM) programme commenced in Ireland in 2011. The CFRAM programme was implemented in Ireland so as to meet the requirements of the EU "Floods" Directive (2007/60/EC). This Directive was transposed into Irish law with the SI 122/2010, which set out the responsibilities of the OPW (Office of Public Works) and other public bodies in the implementation of the Directive, on consultation, and details the process for implementation of the measures set out in the flood risk management plans (CFRAM programme).

The CFRAM programme comprises of three phases: (i) the Preliminary Flood Risk Assessment (PFRA), completed in 2011; (ii) the CFRAM studies (flood maps), completed in 2014; (iii) the preparation of Flood Risk Management, to be completed in 2015. The CFRAM flood hazard maps are used as part of this work to have a spatial estimate of the flood hazard; fluvial flood events are shown for 10, 2 and 1\% Annual Exceedance Probability (AEP). The AEP is estimated using computer models to predict how and where flooding is likely to occur and what receptors are likely to be affected by the flooding [10].

\section{B. House prices}

The economic dataset on the Irish housing used for this study contains a list of all the properties advertised online for sale from 2006 to 2015. All the properties included in the used database are geolocated and have information on a number of property characteristics such as the number of bedrooms/ bathrooms, and property type (detached, semi-detached, bungalow etc.).

\section{Case study of the Dodder Catchment (South County Dublin)}

The River Dodder rises in the Dublin Mountains and flows through many residential areas of Dublin including the suburban areas of Tallaght and Rathfarnham and through the city areas of Donnybrook and Ballsbridge before discharging into the River Liffey estuary at Ringsend. The lower section of the river is tidal up to Ballsbridge. The River Dodder has a history of flooding and is known as a river which responds quickly to a rainstorm event [11], mostly because of the steep gradient of the river in its upper section. In the last century it has overflowed its banks on numerous occasions causing damage to adjacent properties. In 1986 when Hurricane Charley hit Dublin, over 300 properties surrounding the Dodder catchment were flooded [12]. Another significant event occurred on the 1st of February 2002 when a very strong high tide occurred and over 600 properties were flooded on the lower Dodder downstream of Lansdowne Road Bridge [13]. The same magnitude of flood occurred again on the 24th of October 2011 when a similar number of properties were flooded throughout the catchment.

\section{METHODS}

Stated and revealed preference methods have been used in literature to assess flood risks, with either method having its own advantages and disadvantages [4, 14]. Stated preference methods are based on interviews to individuals about their willingness to pay for reduced flood risk exposure: the major disadvantage of this methods is that it is unclear if the actual behavior of the interviewed people corresponds to their actual potential behavior [15]. The revealed preference method deals with actual consumer behavior in markets: the disadvantage of this approach is its limit to assess willingness to pay (WTP) values in different (real-world) scenarios, and one cannot readily control the information shaping the risk perception of individuals $[16,17]$.

The study presented in this paper uses the revealed preference approach by assuming that the presence of the flood risk is considered by the buyer when choosing the location of a house. As such, the other underlining assumption is that house prices reveal individual preferences regarding the acceptance of 
risk: this is a reasonable assumption if appropriate controls for differences in the property and the location are included [18]. In this paper, such differences are set as neighborhood or location characteristics and assessed by controlling the variance between prices of houses located inside and outside the flood risk zone. Observed house prices and the specific amounts of characteristics associated with house define a set of implicit or "hedonic" prices [19], as described in the following section.

\section{A. Evaluation of flood risk: hedonic regression}

A housing unit is considered as a differentiated market good representing a set of hedonic prices as a bundle of quantitative and qualitative characteristics: hedonic prices are defined as the implicit prices of attributes and are revealed to economic agents from observed prices of differentiated products and the specific amounts of characteristics associated with them [19]. This approach has the advantage of being able to control for every element that potentially affects house prices; the disadvantages though are the impossibility to control for the potential bias in subjective individual perceptions of the level of risk and the coincidence of waterrelated amenities and water-related risks.

The problem arising from the coincidence of positive and negative amenities related to proximity to the water is solved in this paper by using geographic information systems (GIS) to account for the spatial organization of the data in terms of distance to the water front and elevation. This approach allows to assess where amenities and risk do not exactly coincide, i.e. houses on hillsides with a direct view towards a river. This problem is addressed in the meta-analysis by controlling for the inclusion of distance and elevation related variables in the primary studies.

GIS is used to spatially characterize the houses included in the analysis by linking them to the following set of parameters included into the baseline regression: house price, house type and size (number of bedrooms and bathrooms), when it was on the market, and its location. The location is considered in the baseline regression model as a general location variable (e.g. Census ED).

Once the baseline regression model is built, then the variables included in it are regressed against the amenity of interest for the work presented here: the flood-risk. This is treated by constructing (in GIS) $0 / 1$ variables denoting whether a particular listing is in a flood zone (flood events occurrence probability $1 \%, 2 \%, 10 \%)$. The result of this procedure is the estimate of the percentage impact on a house price of being in a specific flood-risk zone, compared to not being in it. The distance from between a set of amenities and the properties is also calculated using GIS. The amenities included in this procedure are: the Central Business Districts (CBDs), rivers, lakes, schools, green spaces, rail facilities and the coastline.

Analysis was undertaken using a hedonic price regression, where there were two key variables of interest: being within/near the $1 \%$ flood risk zone (i.e. a risk of flooding once every hundred years) and being within/near areas that have been subject to Dodder flood events. Additional controls were included as follows:
1. The month and year that the property was listed, as during the ten-year period (2006-2015), housing prices in Dublin were extremely volatile

2. The size of the property, as measured in bedrooms and bathrooms (a standard measure in the Dublin housing market)

3. Other dwelling attributes, including housing type (apartment, detached, semi-detached, terraced or bungalow), and whether the dwelling was part of a new development and/or had a garden

4. Controls for location, using Census tract fixed effects (specifically, 334 District Electoral Divisions)

5. Other location attributes, including distance to the city center, the coastline, the nearest lake, the nearest river, elevation and slope - some of these would be expected to be strongly collinear with flood risk and are thus necessary to better estimate the causal effect of flood risk

6. Other neighborhood attributes, including local unemployment rate, percentage with a degree, average dwelling size, the fraction of dwellings dating from before 1914 , the fraction in local authority housing, population density, and distance to the nearest primary and secondary schools, and nearest rail station.

\section{RESULTS}

Results from the analysis are presented in the Table below. In Model 0, only controls outlined in points (1)-(3) above were included. In particular, no location fixed effects were included. This suggests a number of implausible results, including a large premium $(+10.7 \%)$ for a property being located within areas affected by historical flood events. This is likely due to a number of high-income areas being located near the Dodder, relative to the control group (100m-200m away). This result disappears once location controls are included (Model 1).

Once location fixed effects are included, there is a clear negative impact of being within the Dodder flood event zone but no clear impact of being within the Dodder $1 \%$ risk zone. This is shown in Figures 1 and 2 below. Relative to properties 100-200 meters away from the zone of historical flood events, properties inside that zone had during the period covered roughly $3 \%$ lower prices, everything else being equal. There is some evidence of a mild river amenity specific to the Dodder also, as properties $100-200 \mathrm{~m}$ away were on average more valuable than those further away.

However, relative to the $1 \%$ risk zone - and controlling for a full range of dwelling, location and neighborhood attributes (Model 3) as well as Dodder flood events - there is if anything a positive premium, although this is not statistically significant. Indeed, once location controls are included, there is no statistically significant difference between properties inside the $1 \%$ risk zone, properties $0-100 \mathrm{~m}$ from the zone and the control group (100-200m away). These properties all have statistically significant higher values on average than those properties at least $200 \mathrm{~m}$ away, once sufficient controls for location and other natural amenities are included. 
TABLE I. REGRESSION RESULTS (OVERVIEW)

\begin{tabular}{|c|c|c|c|c|c|}
\hline Spatial Location & $\begin{array}{r}\text { Model } \\
0\end{array}$ & $\begin{array}{r}\text { Model } \\
1\end{array}$ & $\begin{array}{l}\text { Model } \\
2\end{array}$ & $\begin{array}{r}\text { Model } \\
\mathbf{3} \\
\end{array}$ & $\begin{array}{r}\text { Model } \\
4 \\
\end{array}$ \\
\hline $1 \%$ zone: Inside & $-5.9 \%$ & $-0.7 \%$ & $-1.1 \%$ & $1.2 \%$ & $-1.3 \%$ \\
\hline $1 \%$ zone: $0-100 \mathrm{~m}$ & $-6.4 \%$ & $0.6 \%$ & $0.8 \%$ & $0.7 \%$ & $0.0 \%$ \\
\hline $1 \%$ zone: $100-200 m$ & $0.0 \%$ & $0.0 \%$ & $0.0 \%$ & $0.0 \%$ & $0.0 \%$ \\
\hline $1 \%$ zone: $200-300 m$ & $-0.9 \%$ & $-1.3 \%$ & $-1.3 \%$ & $-2.6 \%$ & $-2.3 \%$ \\
\hline $1 \%$ zone: $300-400 \mathrm{~m}$ & $-0.7 \%$ & $-3.7 \%$ & $-4.3 \%$ & $-4.3 \%$ & $-4.4 \%$ \\
\hline $1 \%$ zone: $400-500 \mathrm{~m}$ & $7.3 \%$ & $-2.3 \%$ & $-3.4 \%$ & $-4.2 \%$ & $-5.0 \%$ \\
\hline $1 \%$ zone: $500 \mathrm{~m}+$ & $31.4 \%$ & $3.5 \%$ & $0.8 \%$ & $-1.6 \%$ & $-1.8 \%$ \\
\hline Event zone: Inside & $10.7 \%$ & $-3.1 \%$ & $-3.4 \%$ & $-3.4 \%$ & $-2.8 \%$ \\
\hline Event zone: $0-100 \mathrm{~m}$ & $5.9 \%$ & $0.0 \%$ & $-0.1 \%$ & $-0.9 \%$ & $-0.6 \%$ \\
\hline Event zone: $100-200 \mathrm{~m}$ & $0.0 \%$ & $0.0 \%$ & $0.0 \%$ & $0.0 \%$ & $0.0 \%$ \\
\hline Event zone: $200-300 \mathrm{~m}$ & $-2.3 \%$ & $-0.5 \%$ & $-0.5 \%$ & $-0.2 \%$ & $-0.9 \%$ \\
\hline Event zone: $300-400 \mathrm{~m}$ & $-7.3 \%$ & $-0.5 \%$ & $-0.2 \%$ & $-0.5 \%$ & $-1.8 \%$ \\
\hline Event zone: $400-500 \mathrm{~m}$ & $-11.9 \%$ & $-2.9 \%$ & $-2.2 \%$ & $-1.4 \%$ & $-2.5 \%$ \\
\hline Event zone: $500 \mathrm{~m}+$ & $-23.8 \%$ & $-4.1 \%$ & $-2.9 \%$ & $-0.5 \%$ & $-1.0 \%$ \\
\hline Time Controls & Yes & Yes & Yes & Yes & Yes \\
\hline Dwelling Attributes & Yes & Yes & Yes & Yes & Yes \\
\hline Census Fixed Effects & No & Yes & Yes & Yes & Yes \\
\hline Locational Amenities & No & No & Yes & Yes & Yes \\
\hline $\begin{array}{l}\text { Neighbourhood } \\
\text { Attributes }\end{array}$ & No & No & No & Yes & Yes \\
\hline Flood risk/history & Joint & Joint & Joint & Joint & Separate \\
\hline $\mathbf{N}$ & 158,890 & 158,890 & 158,890 & 158,890 & 158,890 \\
\hline $\mathbf{R} 2$ & 0.539 & 0.795 & 0.796 & 0.809 & 0.808 \\
\hline RMSE & 0.361 & 0.241 & 0.241 & 0.233 & 0.233 \\
\hline p value & $<0.05$ & $<0.05$ & $<0.05$ & $<0.05$ & $<0.05$ \\
\hline SE & 0.012 & 0.070 & 0.073 & 0.072 & 0.072 \\
\hline
\end{tabular}

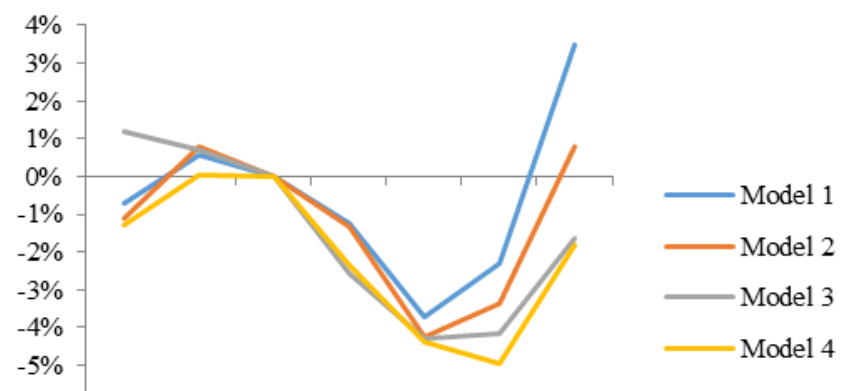

$-6 \%$

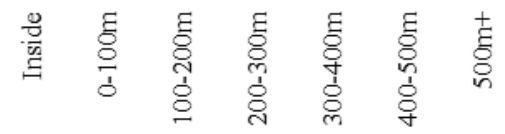

Fig. 1. Impact on house prices of proximity to Dodder $1 \%$ risk zone.

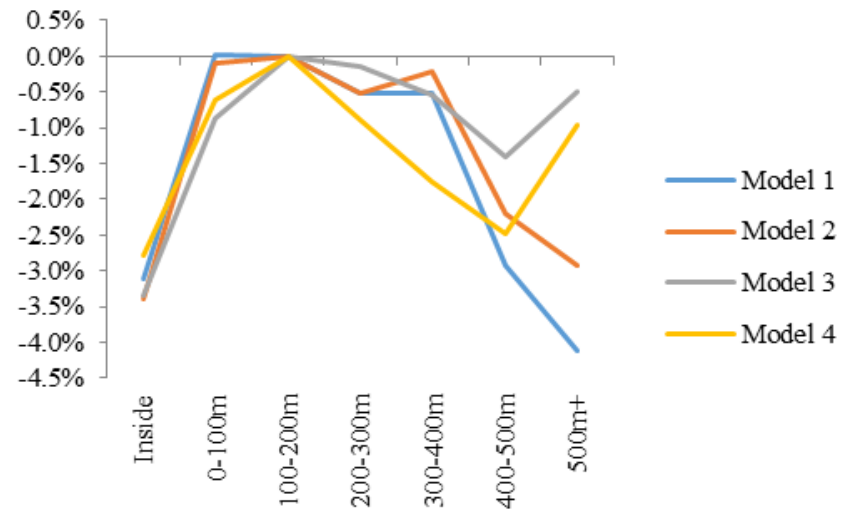

Fig. 2. Impact on house prices of proximity to Dodder flood events.

\section{DISCUSSION}

The regression analysis for the sales shows that there is little evidence that being within the $1 \%$ risk zone has any impact on house prices. Going from within the risk zone to $\sim 150 \mathrm{~m}$ away is associated with a slight increase in prices $(\sim 1 \%)$ and this is not statistically significant, accounting for a full range of local characteristics. However, being within the historical events zone does have a negative effect on prices, $3.4 \%$ and (strongly) statistically significant. Interestingly, it emerges that wrong conclusions could be potentially draw if flooding events are not controlled for: the relationship between prices and being within the $1 \%$ zone is indeed negative if flood events are not included in the analysis (although again not statistically significant). This is explained by the fact that people may have an understanding of flooding that is more adaptive (i.e. learning/extrapolating from the past) than rational (a cool assessment of risk).

\section{CONCLUSIONS}

This study uses an integrated method of GIS-based functions and hedonic property price function, as a statistical based algorithm, to estimate and quantify the effects of the properties being located within a flood risk and/or a flood event zone. The aim of this procedure is to obtain an estimate of the percentage impact on a house price of being in a specific floodrisk zone, compared to not being in it. The distance from between a set of amenities and the properties is also calculated using GIS. The amenities included in this procedure are: the Central Business Districts (CBDs), rivers, lakes, schools, green spaces, rail facilities and the coastline.

The assessment is completed utilizing data from sales of 158,890 properties between 2006 and 2015 in the house market in Dublin, within areas at risk of flooding from the Dodder River. It is concluded that a house located within the $1 \%$ risk zone has a similar market value than an equivalent house located outside the floodplain. However, being within the historical events zone does have a negative effect on prices, $3.4 \%$ and (strongly) statistically significant.

In general, the analysis demonstrates that the prices of the house located within a floodplain are significantly affected by the distance from a set of amenities such as the Central Business Districts (CBDs), rivers, lakes, schools, green spaces, 
rail facilities and the coastline. Most importantly, the assessment presented in this paper shows the crucial importance of controlling for flooding events in the analysis: the relationship between prices and being within the $1 \%$ zone is indeed negative if flood events are not included in the analysis. As such, this work also proves that people may have an understanding of flooding that is more adaptive than rational.

Finally, the work presented in this paper also demonstrates the effectiveness of using GIS for this type of analysis to solve the problem arising from the coincidence of positive and negative amenities related to proximity to the water and to account for the spatial organization of the data in terms of distance to the water front and elevation.

\section{REFERENCES}

[1] IPCC, IPCC Fourth Assessment Report: Climate Change 2007, Geneva, Switzerland, 2007.

[2] G. P. Guarín, C. Westen, and L. Montoya, "Community-based flood risk assessment using GIS for the town of San Sebastian, Guatemala," International Institute for Geoinformation Science and Earth Observation (ITC), 2004.

[3] W. Kron, "Flood risk= hazard x exposure x vulnerability," Science Press, New York, 2003.

[4] V. E. Daniel, R. J. Florax, and P. Rietveld, "Flooding risk and housing values: An economic assessment of environmental hazard," Ecological Economics, vol. 69, no. 2, pp. 355-365, 2009.

[5] A. Zerger, "Examining GIS decision utility for natural hazard risk modelling," Environmental Modelling \& Software, vol. 17, no. 3, pp. 287-294, 2002.

[6] D. S. Brookshire, M. A. Thayer, J. Tschirhart, and W. D. Schulze, "A test of the expected utility model: Evidence from earthquake risks," The Journal of Political Economy, pp. 369-389, 1985.

[7] S. D. Shultz, and P. M. Fridgen, "Floodplains and Housing Values: Implications for Flood Mitigation Projects1," Wiley Online Library, 2001.
[8] C. Kousky, "Learning from extreme events: risk perceptions after the flood," Land Economics, vol. 86, no. 3, pp. 395-422, 2010.

[9] R. C. Lyons, "Inside a bubble and crash: Evidence from the valuation of amenities," Available at SSRN 2007530, 2013.

[10] R. Berry, M. Horritt, C. Dewar, S. Baigent, and J. Martin, "Development of flood mapping formats for the lee catchment flood risk assessment \& management study," in Irish National Hydrology Conference 2008, 2008.

[11] R. Bradford, J. O'Sullivan, I. Van der Craats, J. Krywkow, P. Rotko, J. Aaltonen, M. Bonaiuto, S. D. Dominicis, K. Waylen, and K. Schelfaut, "Risk perception-issues for flood management in Europe," Natural Hazards and Earth System Science, vol. 12, no. 7, pp. 2299-2309, 2012.

[12] E. De Bruijn, and T. Brandsma, "Rainfall prediction for a flooding event in Ireland caused by the remnants of Hurricane Charley," Journal of Hydrology, vol. 239, no. 1, pp. 148-161, 2000.

[13] P. Javelle, T. B. Ouarda, M. Lang, B. Bobée, G. Galéa, and J.-M. Grésillon, "Development of regional flood-duration-frequency curves based on the index-flood method," Journal of Hydrology, vol. 258, no. 1, pp. 249-259, 2002.

[14] M. M. Keen, M. P. K. Freeman, and M. M. Mani, Dealing with increased risk of natural disasters: challenges and options: International Monetary Fund, 2003

[15] J. A. List, and C. A. Gallet, "What experimental protocol influence disparities between actual and hypothetical stated values?," Environmental and Resource Economics, vol. 20, no. 3, pp. 241-254, 2001.

[16] A. T. de Blaeij, and D. J. van Vuuren, "Risk perception of traffic participants," Accident Analysis \& Prevention, vol. 35, no. 2, pp. 167$175,2003$.

[17] R. J. Florax, C. M. Travisi, and P. Nijkamp, "A meta-analysis of the willingness to pay for reductions in pesticide risk exposure," European Review of Agricultural Economics, vol. 32, no. 4, pp. 441-467, 2005.

[18] R. L. Watts, and J. L. Zimmerman, "The demand for and supply of accounting theories: the market for excuses," Accounting Review, pp. 273-305, 1979.

[19] S. Rosen, "Hedonic prices and implicit markets: product differentiation in pure competition," The journal of political economy, pp. 34-55, 1974. 